\title{
Inhaled tiny mica flakes and vitamin B12 intercalated clay dust induce multiple sclerosis
}

Seppo K Junnila*

Health Centre of The Town of Haapajärvi, Haapajärvi, Finland

Received: April 6, 2016

DOI: $10.5430 /$ jer.v2n2p102
Accepted: May 24, 2016

Online Published: June 1, 2016

\begin{abstract}
The incidence and prevalence of multiple sclerosis (MS) have increased much since 1950s. Environmental factors must play a decisive role because the heredity can not be mutated so fast. No one has proposed the mechanical pathway between MS and environmental factors. The aim of this study is to reveal what environmental factors induce multiple sclerosis. From animal models it is known that aggresive $\mathrm{T}$ cells (able to cross bloob-brain barrier) are induced in lung. Soil dust containing both weathered mica particles and vitamin B12 containing clay particles ("transformation smectite" particles ) can activate myelin specific CD4+ T cells in lung. CD4+ central memory type T cell (resting phenotype) receptor is activated by soluble MHC II when it is anchored on mica particle surface and $\mathrm{T}$ cell adheres also on the same mica surface. Further prerequisite is that at the same time smectite clay particle intercalated with vitamin B 12 is endocytosed into the same T cell. T cell activation requires 1) $\mathrm{T}$ cell receptor activation and 2) $\mathrm{T}$ cell metabolic changes from oxidative phosphorylation to aerobic glycolysis. In classical activation model co-receptor B 28 activation changes T cell metabolism to oxidative glycolysis. In this case at the wrong time dosed vitamin B 12 changes T cell metabolism to oxidative glycolysis using anaplerotic feeding of TCA-cycle, permitting $\mathrm{T}$ cell activation to effector phenotype aggressive $\mathrm{T}$ cell. The hypothesis is based on new findings in immunobiology and on epidemiological observations.
\end{abstract}

Key Words: Myelin specific T cells, Soil digging, Multiple sclerosis clusters, Soil vitamin B12, Soluble MHC II, Mica, T cell metabolism

\section{INTRODUCTION}

Multiple sclerosis (MS) is the commonest devastating neurodegenerative disease in young adults in high latitudes. ${ }^{[1]}$ MS is an autoimmune or immune disease, the diagnostic criteria of which are established and the epidemiological reports are quite reliable. We are now experiencing the MS epidemic in many countries e.g. in Finland, ${ }^{[2]}$ in Sardinia (Italy), ${ }^{[3]}$ in $\mathrm{USA}^{[1]}$ and in Iran. ${ }^{[4]}$ Typically females have a greater risk for MS than males as for many other autoimmune diseases. ${ }^{[2]}$
The current epidemic began in the 1950s.

Epidemiological studies have revealed a complex genetic susceptibility, but only HLA-locus HLA-DRB1 is cosistently associated with the risk to get MS. ${ }^{[5]}$ Typical for the incidence of MS is clustering in space and time. ${ }^{[6-8]}$ In fact there are enormous literature concerning the MS clusters. Very interesting is the cluster that develops in an area where MS has been earlier unknown such as Faroe Islands, situated in North Atlantic between Iceland, Norge and Scotland. The

*Correspondence: Seppo K Junnila; Email: seppo.junnila@pp.inet.fi; Address: Siiponkoskentie 28, Haapajärvi 85800, Finland. 
outbreak of MS epidemic in Faroe Islands has aroused much interest in the field of medical research. British Troops occupated Faroe Islands in April 1940 for five years. The earliest date when MS symptoms were found in native-born Faroes was July 1943. Research concerning MS epidemic in Faroe Islands has continued some thirty years. As a summary from the research it is thought that British Troops introduced the specific but unknown infection into the Islands. ${ }^{[9]}$

British Troops also modified the enviroment in the Islands thorougly. They introduced the first caterpillars and diggers into the Islands and built the airport, much roads and the battery positions aroud the seashore. For the first time in the history of the Islands large quantities of soil dust was raised from the earth and the Faroes breathed the dust. School children at Henribourg, Saskatchewan, Canada, breathed soil dust during the World War II, when The Air Forces of Canada used the ancient overgrown lake as an exercise targert for bombers near Henribourgh, where then lived less than 75 people. Later eight school children (classmates) develop MS plus two miltary personel, who had resided in the close proximity. Causative factor(s) was never identified. One diligent victim, however, said that the cause was the bombing. Is it possible that he or she was right ${ }^{[8]}$ ?

\section{Pathophysiology of MS}

The central hallmarks in MS development are the inflammatory plaques. Plaques are situated in the brain white matter and spinal cord and also in the gray matter. Plaque distribution is quite ramdom. The plaque originates from the leak in blood-brain barrier (BBB). Activated myelin reactive CD4+ T lymphocytes can adhere and traverse the blood vessel in the brain. MS patients and healthy persons both have myelin reactive CD4+ $\mathrm{T}$ cells in their peripheral blood, however, phenotypically these cells differ between MS patients and healthy persons. Myelin reactive CD4+ T cells of MS patients are activated effector-memory phenotype, whereas CD4+ T cells from healthy controls are centralmemory phenotype whose physiological function is to induce neuroprotective beneficial autoimmunity after neuronal injury. ${ }^{[10]}$ Only activated effector-memory CD4+ T cells can traverse the blood-brain barrier and attack the myelin sheat. ${ }^{[11]}$

From various CD4+ T cell lineages Th1 and Th17 cells play an essential role in MS, Th17 possibly in the initial phases and Th1 later in the course of the disease. CD4+ lineages are however plastid, so that originally Th17 cells can switch later into Th1 lineage. ${ }^{[12]}$ It is largely accepted, that in MS CD4+ central memory myelin- reactive $\mathrm{T}$ cells are activated in the periphery, with great probability in the lung. In the rat model of MS, experimental autoimmune encephalomyelitis

Published by Sciedu Press
(EAE), it was foud that myelin basic protein (MBP) reactive $T$ cells could not invade to the central nervous system before residing within the lung tissues. MBP reactive $\mathrm{T}$ cells disappeared from blood circulation almost immediately after intravenous injection and they gained the capacity to enter the central nervous system only after residing transiently within the lung tissues. Inside the lung tissues $\mathrm{T}$ cells visited to the airways and used the airways as roads in their way to to bronhus associated lymphoid tisue (BALT) and lung draining mediastinal lymp nodes. MBP reactive $\mathrm{T}$ lymphocytes gain the effector memory phenotype in the lung. Thereafter they could invade to the brain and clinical symptoms of EAE were broken out. ${ }^{[13]}$

Cerebrospinal fluid (CFS) surrounds the brain and is central in the maintaining brain homeostasis. BBB shields the brain from adverse molecules, immune cells and pathogens. However the regulated immune cell entry to the brain is needed to maintain brain plasticity and homeostasis. This regulated immune cell entry takes place in the choroid plexus. Uncontrolled activated myelin specific $\mathrm{T}$ cell invasion from the brain capillaries into the brain tissue is always detrimental. ${ }^{[14]}$ CSF outflow takes place through arachnoid granulation into venous blood and through meningeal lymphatic capillaries into deep cervical lymph nodes. Smaller molecules e.g. peptides are coveyed with CSF through arachnoid granulations into venous blood, which meets it's first filter in lung capillaries. ${ }^{[15,16]}$ If normally circulated myelin specific central-memory $\mathrm{T}$ cells become activated into effectormemory $\mathrm{T}$ cells in the lung for some reason or another, they have the opportunity to meet their own antigens (myelin specific peptides) in lung BALT and they expand clonally. Local inflammation in the brain is possible after the mass of effector-memory $\mathrm{T}$ cell invasion. This mass invasion begins the chain of events that induce clinical MS. So what activates the myelin reactive Th17 cells in lung?

\section{HYPOTHESIS}

A person inhales soil dust which contains 1) weathered mica mineral nanosized flakes and 2) nanosized smectite clay partices intercalated by vitamin B12. In small airways MBP reactive central memory $\mathrm{CD} 4+\mathrm{T}$ cells come in contact with these tiny particles, which activate these CD4+ T cells in a later described manner into effector memory phenotype Th17 cells. These cell are capable to invade into brain and induce MS.

\section{DESCRIPTION OF CD4+ T CELL ACTIVA- TION PATHWAY}

Mica is a phyllosilicate mineral. Mica is common mineral in soils. Mica is one parent mineral of expandible clays 
smectites. Atoms (mainly $\mathrm{Si}$ and $\mathrm{Al}$ ) of mica are bonded together into flat sheets, allowing the perfect cleavage of the mineral, when weathered. The productions are clean, flexible, elastic and tough sheets to a minimal thickness about $1 \mathrm{~nm}$. Polyelectrolytes e.g. many proteins and DNA can be adsorbed on mica surface. ${ }^{[17]}$ When weathered, mica can form "transformation" smectites in the acid podzolic soils. The finer fraction of the mica based phyllosilicates is composed of particles of 3-7 sheets having $20 \mathrm{~nm}$ to $100 \mathrm{~nm}$ in length. Weathered mica also contains empty channels of tubular forms inside the particles. ${ }^{[18]}$

Vitamin B12 intercalates between the smectite layers by expading the space between two layers from about $0.5 \mathrm{~nm}$ to over $1 \mathrm{~nm}$ depending of the cations $(\mathrm{Na}+, \mathrm{K}+\mathrm{Ca}+)$ which vitamin B12 replaces. ${ }^{[19]}$ Cellular uptake of nanoparticles $(50 \mathrm{~nm}-100 \mathrm{~nm})$ decorated with vitamin B12 is dramatically increased compared with native nanoparticles in many cell types. It is thought that B12 decorated nanoparticles are internalized through caveolae in many cell types. ${ }^{[20,21]} \mathrm{CD} 4+$ $\mathrm{T}$ cells do not express caveolin 1 protein, which is typical for caveolae. Dynamin 2 regulates endocytosis in T lymphocytes. ${ }^{\text {[2] }}$ Vitamin B12 decoration of nanoparticles, which usually express own negative surface charge in native state, changes the charge to positive due to seven side chain amino groups in vitamin B12. This may help the endocytosis of vitamin B12 decorated nanoparticles.

Vitamin B12 is very stable compound, however UV light destroys it. The human has vitamin B12 stores in the liver for three years, this would not be possible without extraordinary molecular stability. The basic structure of vitamin B12 is modified tetrapyrrole, tetrapyrrole is the basic structure of porfyrins. Porfyrins (petroporfyrins) are found in the crude oil and in the coal. ${ }^{[23]}$

In nature only some bacteria and archae are capable of synthesizing vitamin B12. All higher living forms depend on vitamin B12 synthesized by bacteria, hence the soil and natural water systema must contain vitamin B12. The upper soils contain vitamin $\mathrm{B} 12$, so that the concentration of vitamin B12 is almost the same as in beef ( 27 microg $/ \mathrm{kg})$. Sevage sludge contains vitamin B12 more than the cow liver $(2,140$ microg/kg). ${ }^{[24]}$

CD4+ T cells are classically thought to become activated when antigen presenting cell e.g. dendritic cell presents its own antigen complexed with MHC II to the T cell receptor (TCR). This antigen presentation demands physical contact between antigen loaded MHCII complex and TCR complex. ${ }^{[25]} \mathrm{CD} 4+\mathrm{T}$ cell activation process does not proceed if $\mathrm{CD} 4+\mathrm{T}$ cells do not change their metabolism from oxidative phosphorylation to aerobic glycolysis. ${ }^{[26]}$ In classi- cal model of CD4+ T cell activation dendritic cell B7 ligands activates $\mathrm{T}$ cell co-receptors $\mathrm{CD} 28$ at the same time with TCR activation. The CD 28 signaling pathway changes CD4+ $\mathrm{T}$ cell metabolism into oxidative glycolysis. ${ }^{[27]}$

It is quite a new observation that soluble MHC II complexes (sMHC II) are also normal constituent of serum and human body fluids. ${ }^{[28]}$ sMHCII with mounted peptide are not able to activate TCR but are considered to be involved in the maintenance of self tolerance and the increase of CTLA-4 receptor expression, which induce suppression in $\mathrm{CD} 4+\mathrm{T}$ cell activity. ${ }^{[29]}$

If sMHCII with mounted peptide is anchored to a suitable surface, it can activate TCR. Suitable surfaces are e.g. moist glass surface and plastic surface. CD4+ T cell actin cytoskeleton must be able to adhere the surface. ${ }^{[25]}$ Mica surface is hydrophilic and is covered with an absorbed thin aqueous layer when relative humidity is high. Actin adheres stably on mica surface of this sort. ${ }^{[30]}$

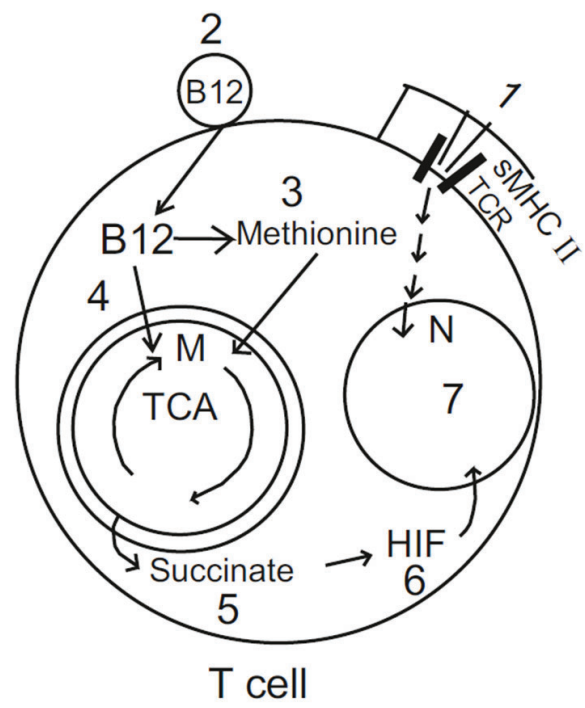

Figure 1. 1. Activation of the myelin reactive $\mathrm{CD} 4+\mathrm{T}$ cell in lung.1. Mica-bound sMHCII activates TCR. T cell is adherent to mica surface. 2. Smectite particle intercalated with vitamin B12 is endocytosed into the cell where vitamin B12 is released. 3. Vitamin B12 dependent methionine synthesis is enhanced in the cytoplasm. Methionine enters the mitochondria. 4. In the mitochondria methionine is metabolized into succinyl-Coa by vitamin B12 dependent manner via propionyl-CoA pathway. Succinyl-CoA enters anaplerotically into TCA cycle and is transformed in the next step of the cycle into succinate. 5. Succinate leaks into the cytoplasm. 6. Succinate activates and stabilizes the transcription factor HIF-1alfa, which enters the nucleus. 7. $\mathrm{T}$ cell receptor signaling pathway induces many transcription factors which activate or switch off genes (M mitochondria, $\mathrm{N}$ nucleus, TCA cycle) 
Soil dust containing weathered mica and "transformation smectites" can get their way into lung. Peptide bound sMHCII complexes are normal constituents of bronchial and alveolar liquid film and can bee adhered onto the present mica surface. Myelin reactive CD4+ T cells can adhere to the same surface and trigger TCR activation (see Figure 1)

CD28 signaling pathway is not activated in this scenario. Metabolic changes parallel to CD28 signaling can be produced by anaplerotic substitutes to TCA-cycle in mitochondria. The cells use TCA-cycle in addition to energy production also to synthetize various molecules e.g. amino acids and nucleotides. This function is named cataplerosis and it takes out the TCA cycle intermediates. TCA-cycle must then be substituted from outside by the anaplerotic feeding. Two substantial anaplerotic feedings into the cycle are glutamine and propionate. Glutaminolysis produces is alfa-ketoglutarate, which is one member in the TCA-cycle and feeds the TCAcycle, when substituted into the cycle from outside. ${ }^{[31]}$ In the TCA cycle next to alfa-ketoglutarate is succinyl CoA. Succinyl CoA is fed into TCA cycle by propionyl CoA pathway. Oxidation of odd-chain fatty acids and amino acids methionine, threonine, isoleucine and valine produce propionyl CoA in mitochondria. Propionyl CoA is metabolized to methylmalonyl CoA. Methylmalonyl CoA is metabolized to succinyl CoA, which is the intermediate in TCA cycle. Proceeding of the reaction from methylmalonyl CoA to succinyl CoA is catalyzed by the enzyme methylmalonyl CoA mutase requiring vitamin $\mathrm{B} 12$ as cofactor. ${ }^{[32]}$

Lymphocytes express the receptor for uptake of vitamin B12 only when activated. This time window lasts only 3-4 days after stimulation. Inactive resting lymphocytes do not uptake vitamin B12. ${ }^{[33]}$ Soil dust nanosized particles decorated with vitamin $\mathrm{B} 12$ can get access into resting CD4+ $\mathrm{T}$ cells at any time, because they do not need the vitamin $\mathrm{B} 12$ receptor. Inside the cell vitamin B12 is released. This happens at the same time when $\mathrm{CD} 4+\mathrm{T}$ cells are adhered onto the micasMHCII complex surface. In cytosol vitamin B12 increases synthesis of methionine and in mitochondria succinyl CoA, resulting in the leakage of succinate into cytosol (see Figure 1). Succinate activates and stabilizes hypoxia inducible transcription factor HIF-1 alfa ${ }^{[34]}$ (see Figure 1). HIF-1alfa is an important transcription factor for selectively driving CD4+ $\mathrm{T}$ cells to Th17 effector-memory phenotype T cells. In this case TH17 cells are myelin reactive effector phenotype and can access into the brain. ${ }^{[35,36]}$

\section{CONTAgion FROM SOIL}

Two high prevalence area of MS in Europe are Finland and Sardinia (isle of Italy). High prevalence area in Finland is
South Ostrobothnia and there especially the drainage basin of river Kyrönjoki (prevalence 100-200 per 100,000). ${ }^{[1]}$ River Kyrönjoki drainage basin is the biggest flood plain in Finland. The prevalence of MS in Sardinia was 150 per 100,000 in the year 1994. ${ }^{[3]}$ Soil pH is low in Finland ${ }^{[37]}$ ) and in Sardinia. ${ }^{[38]}$ Fine grade micas are common in the soils of Finland ${ }^{[39]}$ and Sardinia. ${ }^{[40]}$ Also pedogenic processes produce smectite clay in both areas. In Finland mica and smectite are distributed in the same soil layers (horizons E, B, C).

Land use has intensified in river Kyrönjoki basin during the last fifty years. Perennial grasslands have been interchanged to the ploughed corn fields. River beds has been dug in the years 1930-2004. Villages with high MS frequencies are located along the riversides. ${ }^{[41]}$

Cork oat forests have been common in Sardinia, containing about $20 \%$ of Sardinian surface. Besides production of cork, these forests have been used in grazing. During the last forty years the surface area of cork oat forests has decreased some $30 \%$ and substituted in part by ploughed land. ${ }^{[42]}$ In both river Kyröjoki basin and in Sardinia inhabitants are breathing more soil dust which contains both mica flakes and smectite-vitamin B12 combination particles in micro-nanosized classes.

\section{LIVING THROUGH MS EPIDEMIC}

In Haapajärvi (Finland, North-Ostrobothnia) area there was dug the old river beads and wholly new river beads with the great regulating reservoirs in the years 1967-1979. Later we could find MS epidemic in the area. Most victims lived very near the new river beds or worked in the building sites.

Besides MS, also other peculiar central nervous system diseases could be found e.g. atrophia cerebri, paresis supranuclearis and malign narcolepsia. In one family there was two Ms patients, in the other, one sibling had MS and the other had acute leucemia in early adulthood age. One fatal lung disease in young age could also be found. We could not link these cases to the earth digging before finding the mechanistic pathway from the soil to the brain via the pathogenic CD4+ T lymphocytes.

\section{Conclusion}

The represented hypothesis is based on many new findings in immune biology e.g. soluble MHCII molecules and the dependency of $\mathrm{T}$ cell activation on metabolic reprogramming and consequently it would not has been possible to generate the hypothesis much earlier. If represented hypothesis becomes largely accepted after testing, we must change the soil use and the soil digging practices. The final goal is to reduce the incidence of MS and it seems to be possible. 


\section{REFERENCES}

[1] Khuder SS, Foos M, Herial NA, et al. Urban/rural differences in hospital admissions with multiple sclerosis in selected counties in Ohio 1999-2004. The Open Epidemiology Journal. 2009; 2: 51-54. http://dx.doi.org/10.2174/1874297100902010051

[2] Holmberg M, Murtonen A, Elovaara I, et al. Increased female MS incidense and differences in gender-specific risk in medium- and high-risk regions in Finland from 1981-2010. Mult Scler Int. 2013; 2013: 182516.

[3] Granieri E, Casetta I, Govoni V, et al. The increasing incidence and prevalence of MS in a Sardian province. Neurology. 2000; 55: 842-847. PMid:10994006

[4] Etemadifar M, Sajjadi S, Nasr Z, et al. Epidemiology of multiple sclerosis in Iran: a systematic review. Eur Neurol. 2013; 70: 356-363. PMid:24192707 http://dx.doi.org/10.1159/000355140

[5] Kenealy SJ, Pericak-Vance MA, Haines JL. The genetic epidemiology of multiple sclerosis. J Neuroimmunol. 2003; 143: 7 12. PMid:14575907 http://dx.doi.org/10.1016/j.jneuroi m. 2003.08.005

[6] Pugliatti M, Riise T, Sotgiu MA, et al. Evidence of early childhood as the suspceptibility period in multiple sclerosis: space-time cluster analysis in a Sardinian population. Am J Epidemiol. 2006; 164: 326-333. PMid:16754634 http://dx.doi.org/10.1093/aje/k wj 190

[7] Hopkins RS, Indian RW, Pinnow E, et al. Multiple sclerosis in Galion, Ohio: prevalence and results of a case-control study. Neuroepidemiology. 1991; 10: 192-199. PMid:1745329 http://dx.doi.org/1 $0.1159 / 000110269$

[8] Hader WJ, Irvine DG, Schiefer HB. A cluster-focus of multiple sclerosis at Henribourg, Saskatchewan. Can J Neurol Sci. 1990; 17: 391-4. PMid:2276096

[9] Kurtzke JF, Heltberg A. Multiple sclerosis in the Faroe Islands: an epitome. Journal of Clinical Epidemiology. 2001; 54: 1-22. http://dx.doi.org/10.1016/S0895-4356(00)00268-7

[10] Knipnis, Mishari T, Ben-Nun A, et al. Myelin specific Th1 cells are necessary for post-traumatic protective autoimmunity. J Neuroimmunol. 2002; 130: 78-25. http://dx.doi.org/10.1016/S0165 $-5728(02) 00219-9$

[11] Frohman EM, Racke MK, Raine CS. Multiple sclerosis- the plague and its pathogenesis. N Eng J Med. 2006; 354: 942-55. PMid:16510748 http://dx.doi.org/10.1056/NEJMra052130

[12] Rostami A, Ciric B. Role of Th17 cells in the pathogenesis of CNS inflammatory demyelination. J Neurol Sci. 2013; 333(0): 7687. PMid:23578791 http://dx.doi.org/10.1016/j.jns. 201 3.03 .002

[13] Odoadri F, Sie C, Streyl K, et al. T cells become licensed in the lung to enter the central nervous system. Nature. 2012; 488: 675-9. PMid:22914092 http://dx.doi.org/10.1038/nature11337

[14] Schwartz M, Kipnis J, Rivest S, et al. How do immune cells support and shape the brain in health, disease and aging. The Journal of Neuroscience. 2013; 33: 17587-17596. PMid:24198349 http://dx.doi .org/10.1523/JNEUROSCI . 3241-13.2013

[15] Upton ML, Weller BM. The morphology of cerebrospinal fluid drainage pathways in human arachnoid granulations. Journal of Neurosurgery. 1985; 63: 867-875. PMid:4056901 http://dx.doi.org /10.3171/jns.1985.63.6.0867

[16] Kapoor KG, Katz SE, Grzybowski DM, et al. Cerebrospinal fluid outflow: an evolving perspective. Brain Res Bull. 2008; 77: $327-$ 34. PMid:18793703 http://dx.doi.org/10.1016/j.brainre sbull.2008.08.009
[17] Rojas OJ. Adsorption of polyelectrolytes on mica. Encyclopedia of Surface and Colloid Science, ed. Arthur T Hubbard, CRC Press. 2002.

[18] Aoudjit H, Elsas F, Righi D, et al. Mica weathering in acidic soils by analytical electron microscopy. Clay Minerals. 1996; 31: 319-332. http://dx.doi.org/10.1180/claymin.1996.031.3.03

[19] Kliewer KE, Morra MJ. Sorption and redox activity of cobalt corrinoids on hectorite. Soil Sci Soc Am J. 1998; 62: 916-922. http: // dx.doi.org/10.2136/sssaj1998.03615995006200040010x

[20] Fowler R, Vllasaliu D, Trillo FF. Nanoparticle transport in epithelial cells: pathway switching through bioconjugation. Small. 2013; 9 : 3282-94. http://dx.doi.org/10.1002/smll.201202623

[21] Fowler R, Vllasaliu D, Falcone FH, et al. Uptake and transport of B12-conjugated nanoparticles in airway epithelium. J Control Release. 2013; 172: 374-381. PMid:24008152 http://dx.doi.org /10.1016/j.jconrel.2013.08.028

[22] Willinger T, Staron M, Ferguson SM, et al. Dynamin 2-dependent endocytosis sustains T-cell receptor signaling and drives metabolic reprogramming in T lymphocytes. Proc Natl Acad Sci USA. 2015; 112: 4423-4428. PMid:25831514 http://dx.doi.org/10.1073 /pnas. 1504279112

[23] Callot HJ, Ocampo R, Albrecht P. Sedimentary porphyrins: correlations with biological precursors. Energy et Fuels. 1990; 4: 635-639. http://dx.doi.org/10.1021/ef00024a002

[24] Mozafar A. Enrichment of some B-vitamins in plants with application of organic fertilizers. Plant and Soil. 1994; 167: 305-311. http: //dx.doi.org/10.1007/BF00007957

[25] Ma Z, Sharp KA, Janmay PA, et al. Surface-anchored monomeric agonist pMHCs alone trigger TCR with high sensitivity. Plos Biol 2008; 6: e43. PMid:18303949 http://dx.doi.org/10.1371/j ournal.pbio. 0060043

[26] Loftus RM, Finlay DK. Immunometabolism: cellular metabolism turns immune regulator. J Biol Chem. 2016; 291: 1-10. PMid:26534957 http://dx.doi.org/10.1074/jbc.R115.69 3903

[27] Frauwirth A, Riley JL, Harris MH, et al. The CD28 signaling pathway regulates glucose metabolism. Immunity. 2002; 16: 769-777. http://dx.doi.org/10.1016/S1074-7613(02)00323-0

[28] Aultman D, Adamashvili I, Yaturu K, et al. Soluble HLA in human body fluids. Human Immunology. 1999; 60: 239-244. http: //dx.doi .org/10.1016/S0198-8859(98)00122-0

[29] Bakela K, Kountourakis N, Aivaliotis M, et al. Soluble MHC-II proteins promote suppressive avtivity in CD4+ T cells. Immunology. 2015; 144: 158-169. PMid:25053509 http://dx.doi.org/10.11 11 /imm. 12360

[30] Nicolau DV, Watson GS, Cahill C, et al. Actin adsorbed on HOPG and mica substrates: characterization and manipulation by atomic force microscopy. NSTI-Nanotech. 2004; 1: 103-105.

[31] Wang R, Dillon CP, Shi LZ, et al. The transcription factor Myc controls metabolic reprogramming upon $\mathrm{T}$ lymphocyte activation. Imunity. 2011; 35: 871-882. PMid:22195744 http://dx.doi.org /10.1016/j.immuni.2011.09.021

[32] Reszko AE, Kasumov T, Pierce BA, et al. Assessing the reversibility of the anaplerotic reactions of the propionyl-CoA pathway in heart and liver. Journal of Biological Chemistry. 2003; 278: 34959 34965. PMid:12824185 http://dx.doi.org/10.1074/jbc.M30 2013200

[33] Hall CA. The uptake of vitamin B12 by human lymphocytes and the relationships to the cell cycle. J Lab Clin Med. 1984; 103: 70-81. PMid:6690641

[34] Selak MA, Armour SM, MacKenzie ED, et al. Succinate links TCA cycle dysfunction to oncogenesis by inhibiting HIF-alfa prolyl 
hyroxylase. Cancer Cell. 2005; 7: 77-85. PMid:15652751 http:

//dx.doi.org/10.1016/j.ccr.2004.11.022

[35] Yang K, Chi H. Metabolic control of Th 17 cell generation and CNS inflammation. J Neurol Neurophysiol. 2014; S12: 004.

[36] Ikejiri A, Nagai S, Goda N, et al. Dynamic regulation of Th17 differentiation by oxygen concentrations. Int Immunol. 2012; 24: 137146. PMid:22207131 http://dx.doi.org/10.1093/intimm/dx r111

[37] Myyrä S, Ketoja E, Yli-Halla M, et al. Land improvements under land tenure insecurity the case of $\mathrm{pH}$ and phosphate in Finland. MTT Economic Research, Agrifood Research Finland. Discussion Papers. $2004 / 5$.

[38] Serrasolses I, Perez-Devesa M, Vilagrosa A, et al. Soil properties constraining cork oak distribution. Cork Oak Woodlands on the Edge p 89-99, Aronson et al. eds. 2009. Island Press.
[39] Righi D, Terribile F, Petit S. Pedogenic formation of kaolinitesmectite mixed layers in a soil toposequence developed from basaltic parent material in Sardinia (Italy). Clays and Clay Minerals. 1999; 47: 505-514. http://dx.doi.org/10.1346/CCMN . 1999.0470413

[40] Di Vincenzo G, Carosi R, Palmeri R. The relationship between tectono-metamorphic evolution and argon isotope records in white mica: constraints from in situ $40 \mathrm{Ar}-39 \mathrm{Ar}$ laser analysis of the Variscan Basement of Sardinia. J Petrology. 2004; 45: 1013-1043. http://dx.doi.org/10.1093/petrology/egh002

[41] Wikström J. Studies on the clustering of multiple sclerosis in Finland II: microepidemiology in one high-risk county with special reference to familial cases. Acta Neurol Skandinav. 1975; 51: 173-183. http: //dx.doi.org/10.1111/j.1600-0404.1975.tb07598.x

[42] Sedda L, Delogu G, Dettori S. Forty-four years of land use changes in a Sardinian cork oak agro-silvopastoral system: a qualitive analysis. The Open Forest Science Journal. 2011; 4: 57-66. http: //dx.doi.org/10.2174/1874398601104010057 